\title{
THE FINAL JUDGIIENT AS A BASIS FOR APPEAL
}

\section{CARLETON M. CRICK ${ }^{\circ}$}

IN connection with the mechanics of an appeal two principal problems arise. First, we have the question of the method by which a review may be obtained, and second, the problem of at what stage of the proceeding in the trial court an appeal can be taken. The two are not unconnected, but it is with the second that this paper will mainly be concerned. Decisions of the trial court from which counsel will wish to appeal mayn occur, of course, in many stages of the case. It may be a ruling relating to service of process or an order with regard to the pleadings. Hope for a reversal may be based upon some ruling handed down in a preliminary hearing or during the course of the trial, or it may be some decision made during the process of enforcement of the judgment to which objection is made. A fundamental question necessarily arises, therefore, as to just when the appeal may be taken. The extremes of the proposition are that either each ruling or decision is appealable, or on the other hand, that only when the last or final judgment is rendered can a review be had. In the United States it is agreed that we have taken the second of the two extremes, and all the books concur in the general proposition that appeal can be taken only from a final judgment.. The policy behind this rule is said to be that it is the only way in which the appellate court can prevent itself from being swamped with appeals. The following quotation is typical of many of the cases:

"The apparent object of this statutory restriction on the right of appeal is to prevent the protraction of litigation to an indefinite period by reiterated applications for an exercise of the revisory powers of the appellate tribunal. If, for alleged error

\#A.B. 1928, LL.B. 1930, Kansas, J.S.D. 1931, Yale; member of the Miassachusetts Bar; now practicing in Boston.

This paper was written and the research upon which it is based was done while the writer was Sterling Research Fellow in the Yale Law School, 1930-31. He wishes to acknowledge many helpful suggestions of Professor Thurman W. Arnold, of the Yale School of Law, at whose suggestion the work was originally undertaken.

13 C. J. 432, § 256; 2 R. C. L. 39, § 21; 1 FrEeman on Judgarents (5th ed. 1925) 34, § 22; ElliotT, Appeltate Procedure (1892) 63, § 80; Powell, Appellate Procendings (1872) 129; 2 Spelling, New Trial and Appeltate Practice (1903) 991, $\$ 479$. 
in any interlocutory proceeding, a case could be brought here for revision, a multiplicity of appeals would create vexatious delay, and might eventually result in a ruinous accumulation of costs." 2

But, say the same authorities, there is a regrettable difficulty involved in the application of the rule. ${ }^{3}$ What is a final judgment, and does final always mean final? The treatment of the subject usually takes the form of a statement of the rule in one sentence, followed by many definitions of what constitutes a final judgment (of which the reader may take his choice, depending, presumably, upon what result he wishes to reach), the whole enlivened by variations and refinements set out in voluminous footnotes. ${ }^{4}$ That all has not been well we may gather from no less an authority than the United States Supreme Court when it says with admirable restraint, "Probably no question of equity practice has been the subject of more frequent discussion in this court than the finality of decrees. ... The cases, it must bo conceded, are not altogether harmonious." "

In the present paper the writer proposes to examine this problem of at what point in the case an appeal should be allowed. Did the rule requiring a final judgment arise, as stated above, in the effort to avoid excessive appeals? Does it in fact accomplish that result, and is it suited to the needs and requirements of our modern system of courts?

\section{i}

Systems of law which provide appellate courts for the review of decisions inevitably come into contact with this problem. Thus, when the Roman law, after an early period when there was no relief from the decisions of a magistrate, set up a complicated system of appeals, ${ }^{\circ}$ a practice whereby they were al-

2 Waverly Mut. \& Permanent Land, Loan \& Bldg. Ass'n v. Buck, 64 Md. 338,342 (1885).

3 "The difficulty lies in its (the definition's) concrete application. In applying the test the federal courts seem to have regarded substance rathor than form, and to have been guided by practical rather than by puroly theoretical considerations." DOBIE, HANDBOOK OF FEDERAL JURISDICTION AND Procedure (1928) 792. We may wonder if this is not the author's way of telling us that it is not wise to pay too much attention to the definitions.

4 See 3 C. J. $441 \S 258$, which gives seventeen consecutive definitions of a final judgment.

5 IIcGourkey v. Toledo \& Ohio Cent. Ry., 146 U. S. 536, 544, 13 Sup. Ct. 170, 172 (1892), per Brown, J.

6 At this time it is necessary to make some observations concorning terminology and the methods of appellate review. The paucity of torms in which to deal with the process often results in using the samo word with different meanings in various places. For instance, I havo uscd 
lowed from every decision was found to be burdensome, and among other reforms, appeals were forbidden from interlocutory orders. ${ }^{7}$ The early Germans, on the other hand, developed a method whereby an appeal lay from every decision. ${ }^{8}$

From very early times in England the method whereby a litigant came into the king's court and attacked a decision rendered in a feudal or manorial court was the complaint of false judgment.9 It was early decided, however, that the king's courts could not be charged with a false judgment, ${ }^{10}$ and the means whereby the King's Bench corrected error's in the other common law courts was by writ of error, the method destined to survive in many jurisdictions to our own day. The common law decisions involving writ of error are clearly the origin of our rule that only final judgments are appealable.11 The real factors in the establishment of this practice must go back to the very beginning of the history of the writ of error, and it is impossible at this time to give more than an explanation which is merely plausible.

John de Ralegh's Case ${ }^{12}$ in the 14th Century at least shows

"appeal" (and its derivative adjective, "appellate") as a general term to describe methods by which revieving courts pass on the decisions of the trial courts. But the term, "appeal," also has a technical meaning by which it describes the particular method used in Roman Law, Canon Law, and in chancery proceedings in England. Used thus, it involves some elements of a retrial in the upper court, or at least a consideration of the facts as well as the law of the case. On the other hand, the verb "appellare" was used in the English common law, and in French law to describe the act of a party who brings a criminal charge against another, an "appeal of felony." We look in vain for any account of appeal in the sense of review at common law; such proceedings are discussed in all the books under the title "error," or "false judgment."

7 Engeristann, History of Continental Crvil Procedure (Continental Legal History Series) (1927) 367-9. And see BuckLaND, TExtbook os ROMIAN LAW (1921) 665: "It [appeal] might be on the final judgment or on one of the interlocutory judgments, though some of these latter were unappealable in late law and practically all under Justinian."

82 POLLOCK AND MTATLLAND, HISTORY OF ENGLisH LAW (2d ed. 1899) 666.

(Referred to hereafter as PollocK AND MAATLAND.)

9 FitZHERBERT, NEW NATURA BreVIUM (9th ed. 1794) § 38.

102 POLLOCK AND MIAITLAND 666.

11 This was recognized by Mrr. Justice Lamar in MIcLish v. Rofr, 111 U. S. 661, 12 Sup. Ct. 118 (1891). The writ of error in that case was brought under Section 5 of the Act of Jiarch 3, 1891 (26 Stat. 826, c. 517), which related to the United States Court for the Indian Territory. The section provided for appeals in cases in which the jurisdiction of the court was in issue, but did not mention at what point in the case it should be taken. The Supreme Court held, however, that the question could be raised only on the final judgment, even though this was not required by the Act. MIr. Justice Lamar said that the Judiciary Act of 1789 in limiting appeals to final judgments only declared "a well settled and ancient rule of English practice."

12 Y. B. 17 Ed. 3 (R. S.) 234 (1343). 
some arguments used at that time in connection with the problem. The matter seems to be connected in some way with the "record" by which the proceedings in the lower court are mado known to the King's Bench, for counsel in his argument snys, "You have no warrant to try this record for the record is not fully here, because the case is still pending in another Court. ... It is impossible that on one and the same original writ there should be two records in different courts." This same conception that the record cannot be in two courts at once is found to be present in a number of other early English cases. ${ }^{13}$ What was the nature of this "record"?

The earliest physical evidences of court proceedings extant go back to Richard I, but it seems likely that the practice of enrolling the pleas began under Henry II. ${ }^{1 s}$ Prior to that time, when there was any dispute as to what had occurred in an earlier' case, the justices "bore record" by relying on their memories, 10 and indeed, the origin of our noun, record, which denotes a physical memorandum, seems to have been in the Latin recordari, which meant to remember. ${ }^{10}$ In Middle English (about the period between 1100 and 1400), which is the time now under. discussion, recorden meant to repeat or remember or remind. ${ }^{17}$ If we may believe Stephen, our legal term, record, is of French derivation, brought into English law by the Normans, by whose law recorder, it is said, anciently signified "to recite or testify on recollection as occasion might require, what had passed in court." 18 When, therefore, the practice of enrolling the proceedings in court upon a roll of parchment began, there was a long background of experience when the record was the oral report of proceedings in the original court, and, as Maitland says, "it was long before the theory was forgotten that the rolls of the court were mere aids for the memories of the justices." 10 Thus we have the ancient principle that "the record is properly not in the parchment but in the breast of the judge." 20 It is not $a$

${ }^{13}$ Humphrey Bohun's Case, Y. B. 34 Hen. 6, f. 41a (1456) ; Motcalf's Case, 11 Co. 38a (1615); Spittlehouse vi Farming, Style 200 (1651); Fitzwilliams v. Copley, Dyer 290a (1670).

24 Select Pleas of the Crown (S. S. 1888) vii. I am roferring, of course, to the rolls of court, which later became more and more identifled with the "record."

152 POLLOCK AND Maitland 670.

16 WeBster's New INTERNATIONAL Dictionafy (1925), 1784.

17 Ibid., and at xxiv, $\$ \S 33,34$.

18 Stephen, Common Law Pleading (1897) app. xviii and xix. In old French the noun was recort, which meant remembrance or attostation.

192 PollocK AND MAITLAND 670. Thus in 1292 the bare word of ono justice was preferred to the roll of another who had been guilty of forging records. Ibid. n. 5, cit. Rot. Parl. i, 84-5.

20 Stephen, op. cit. supra note 18, at xix, cit. Y. B. 7 Hen. 6, f. 29 (1418): "Le Record est tout temps en les coeurs do Justices, ct lo Roll 
particular roll of parchment but rather it was, as Coke has put it, "a memorial or remembrance in rolls of parchment," a a mere abstraction, of which the physical memoranda were but evidence.

If we combine with this conception of the record, the fact that a proceeding on a writ of emor seems to have been regarded as a new action, and not merely a continuation of the suit in the inferior court, ${ }^{22}$ we see how it may have been that the record could not be sent up until the suit below had been completed.:3 Suing out a writ of error before final judgment would result in two actions in different courts, to the procedure of each of which the formal record was essential. To remove it while the case was pending below "would disturb the proceedings" there," while the reviewing court could not proceed until it was informed of what had happened below.

But, if duplicate rolls were kept for each case, as seems likely, ${ }^{25}$ then why was it not possible to keep one copy in the trial court and to send the other to the court of error, after which each court could proceed upon the roll before it? The only answer seems to be that there was a conception of unity of the formal record; the roll was not the record but only evidence of

n'est forsque remembrance pur le melioi suerty."

21 Co. LITT. 260 a. The fact that the roll was not the record crops up frequently in the treatises and cases. Thus in SELECT Pleas of THE Crowi (S. S. 1888), case 62, we find the following: "The county and the coroners record that he was not outlawed. But the coroners' rolls and the sheriff's roll testify that he was outlawed." Thus what the coroners record (or testify to) is different from the story told by their rolls..

22 That the writ of error begins a new suit is widely recognized. See the many cases cited in 3 C. J. 304, n. 53. And see 1 Hocnswontu, Histonx OF ENGLISH LAW (3d ed. 1923) 214, quoted infra note 23. The case proceeded in the reviewing court similarly to an ordinary trial of first instance. Thus the plaintiff in error made his complaint (assigned the errors), the defendant in error was summoned by rrit of scirc facias, and there was joinder of issue on the question of whether there was error.

23 It may be noted here that Holdsworth apparently has reached the conclusion that the fact that the writ of error is regarded as a new proceeding is because it could be brought only on final judgments, although he has no citation to support it, and the statement is not at all clear. After discussing the old concept of an appeal or reviev as a charge against the judge, he says: "Two consequences followed logically from the older conception. Firstly, the proceedings (in error) were new proceedings. The case must have been settled by final judgment; and therefore the proceedings taken to upset that judgment were new proceedings. . ." HoLDSTORTH, op. cit. supra note 22 , at 214 .

There is nothing to indicate what was the connection between a proceeding against the judge, and the requirement of final judgment before error could be brought. But it is easy to see why a quasi-criminal proceeding against the judge would be recognized as a new proceeding.

24 See the Spittlehouse case sypra. note 13.

as Select Plaas of the Crown (S. S. 1888) ix. 
it, and it could be in only one court at a time..$^{20}$

Upon this basis then, the argument in John de Ralegh's Case and the other decisions may be explained, but whether it is only a rationalization of a custom with a different origin, or whether the practice started because of some such conceptions as those just discussed it is impossible to say with certainty.

We may note further that in some of the later cases it is said that the words of the writ of error require that the record be sent up "if judgment be thereupon rendered" ${ }^{27}$ so that if the court wishes to label the decision an "award" or an "order" then error does not lie. This has all the earmarks of a mere rationalization to justify an existing practice, but together with the concept of the unity of the formal record, it does serve to indicate that at common law the rule was never thought of as a method of preventing excessive appeals. Of that, at least, we can be reasonably certain. The early time at which the practice was invoked, the 14th Century in John de Ralegh's Case, alone precludes the idea that it arose in the effort to restrict appenls, for in those days the courts were seeking to extend their jurisdiction rather than to narrow it.

However it may have originated, therefore, we may feel assured that in our own time, when appellate courts began to be burdened with appeals, they used as an escape a ready mado device which had its uncertain origin in the dim and remote history of the appellate procedure of the English common lnw. ${ }^{20}$

${ }^{26}$ This statement that the record could only be in one court at a timo is borne out by interesting cases involving writs of error from tho courts of Ireland to the King's Bench in England. The practice was to keep ono roll in Ireland, and to send another copy to the English court. In ono of these cases we find Lord Holt saying: "It is the very record which comes here out of Ireland, and not the transcript of it. . . . Whon tho record ... arrives here then it is the true record, and not before, and that which is in Ireland ceases to be the record." Coot v. Linch, $1 \mathrm{Ld}$. Raym. 427 (1699).

And Yelverton, arguing another case, says: "the reason why at first the transcript is said to be sent only, is for fear it should bo destroyed by the sea in the carriage: but when such fear is over by the safo arrival of the record, and by the entry of it in the rolls here, then it ceases to be a record in Ireland, and is a perfect record here." St. John v. Commyn, Yelv. 117 (1608). And to the same effect see Bishop of Ossory's Cuso, Cr'o. Jac. $534(1620)$. For a 19th Century case showing confusion as to just what the "record" really was, see Richardson v. Mollish, 3 Bing. 346 (1825).

${ }_{27}$ For translations of the writ of error see TmD's PrACTice (2d Am. cd. 1807) 1066; 1 HoLDsworTH, op. cit. supra note 22, at 654;3 BLAOKSTONE Comm. app. no. $3, \S 6$.

28 For other early statements of the rule in English Law, see Co. Lirr. (1st Am. ed. 1853) 288b; 2 Wms. Saund. 100 (1671) BACON's ABr., tit. "Error", A, 2.

Practically all of the cases at Common Law laying down the rule doalt 
A complete picture of appellate processes in England in past years cannot be obtained merely by consideration of the common law courts. Much of the business now handled by our courts of general jurisdiction was taken care of in England by chancery, and we must, therefore, consider the procedure in those types of cases. ${ }^{29}$

Taking Blackstone's time as a convenient point of departure, we find that the course of litigation in a simple case in equity went something as follows..$^{30}$

The pleadings having been filed and the parties at issue upon the facts, the evidence was taken down in writing ${ }^{31}$ and the case set for hearing before the chancellor or the Master of the Rolls. There the evidence was read and such orders made from time to time as might be necessary. ${ }^{32}$ When everything had

with disputes where damages remained to be assessed. Note that this was so as to all of the cases cited in note 13, supra, except Humphrey Bohun's case. Involving accompt, with judgment quod computet is Porter v. Ager, Cro. Jac. 324 (1614). In the following cases error was held not to lie because damages remained to be assessed: Russell and Prat's Case, 1 Leon. 193 (1570) (action on the case for conversion). Elkin v. Wastell, 3 Bulstr. 230 (1617) (action on the case for a promise). Bishop of Glouc. v. Veale, Noy, 66 (1598) (in quare impedit).

In partition, error could not be brought on the judgment quod partitio fiat, but only on the final judgment, quod partitio stalitis sit. Ld. Barliley v. Countess of Warwick, Cro. Eliz. 635 (1598). In ejectment, hovever, error was allowed upon judgment quod recuperet terminum, although damages have not been found. (The judgment quod rccuperet was the one whereby the successful plaintiff was put in possession.) It is said that the possession of the land is the principal thing in question in the suit. Glide v. Dudeney, Style, 109 (1649). As to writs of dower, the cases are conflicting. See Gleford v. Carr, 1 Bromnl. 127 (1651) and an unnamed case in March, N. R. 88 (1642). The rule remained in force in England until the Common Lav Procedure Acts. See Samuel v. Judin, 6 East. 333,336 (1805), per Ellenborough, L. J., "Error can only be brought on final judgment."

29 This of course still leaves out of account the admiralty and ecclesiastic courts which at various times did a considerable business of a type now handled by our courts of general jurisdiction. For the purposes of this paper, however, I have thought it better not to take them up in detail, as they have had practically no existence in this country, and such effect as they may have had upon our procedure has been indirect only, through equity and common law.

${ }^{30}$ For a short outline of the procedure see 3 Blackstone, Cosrar. 442-455. Also 3 WOODDESSON, LECTURES ON THE LAW OF ENGLAND (2d ed. 1834) 213-236. A more complete account is given in the many editions of DANIELL, Chancery Pleading and Practice.

31 This was done by means of written interrogatories to the witnesses before examiners or commissioners authorized by the court for the purpose.

32 These might relate to various matters such as making an election whether to sue at law or equity; orders for subpoenas; for adding de- 
been heard the decree was pronounced. Generally it was merely interlocutory, ${ }^{33}$ but eventually the final decree was made and the rights of the parties completely adjudicated.

We see, then, that there were three types of pronouncements made during the course of a case. First, orders, second, interlocutory decrees, and third, final decrees. ${ }^{34}$ Unlike the common law, however, which as we have seen, required a case to go to final judgment before the decisions of the court might be questioned, equity gave relief from all three types of pronouncements. If a party was dissatisfied by an order made during the course of the proceedings his remedy was by way of rehearing by petition to the Lord Chancellor, whether the cause had been heard before that dignitary or before the Master of the Rolls. On this rehearing the evidence is reread and any additional evidence presented. From the decision on this rehearing an appeal lay to the House of Lords. ${ }^{35}$

An interlocutory decree differed from an order in that it had to be signed by the chancellor before it could be enrolled, and prior to his signing it had only the force of an order. Therefore, prior to signing relief was the same as in the case of an order, namely, petition for a rehearing before the chancellor, and from there appeal to the House of Lords. After a decree was signed and enrolled, whether it was interlocutory or final, relief could be had only by bill of review for an error in judgment appenring on the face of the decree, or by special leave of the chancellor upon the discovery of new evidence. From a decision on this bill appeal might be taken to the House of Lords. ${ }^{30}$

fendants to a bill; to assign a guardian; to set down a demurrer for argttment; to overrule a demurrer; to dissolve an injunction; for a mastor to examine into the regularity of attachments; for a habeas corpus; to cause a report to be made by a master, or to confirm the same; for a subpoena duces tecum. Examples of the form and content of all of the above orders are given in 2 HARRISON, CHANCERY PrACtice (1st Am. ed. 1807) $139-149$.

33 Of course, there were often a number of interlocutory decrees in the same case, with orders interspersed throughout. Some common decrees were as follows: for trial by jury of one or more issues, because "this court is so sensible of the deficiency of trial by written depositions, that it will not bind the parties thereby" (3 BLACKsTone, Comm. 462); submission of questions of law to the common law courts, or referenco mado to a master to settle accounts, and clear up "a hundred little facts" (ibid. $453)$, or to a commission to settle boundaries or arrange a partition.

${ }^{34}$ This seems to be the conventional classification, but as a matter of fact the distinction is not at all clear as between orders and intorlocutory decrees. Daniell, for instance, refers to "decretal orders." See 2 DANibLL, op. cit. supra note 30. (Perkins ed. 1846) 1198. And seo Horwood v. Schmedes, 12 Ves. Jr. 311, 316 (1806).

35 BraCKSTONE, COMM. 454.

36 Ibid. 
Appeal ${ }^{3 \pi}$ to the House of Lords, whether from an order or from an interlocutory or final decree, was by petition to that body, which, if it consented to hear the case, considered all the documents and not merely the enrolled decree. ${ }^{38}$

Thus we see that equity practice never knew the rule of the common law that only final judgments were appealable. Not only could interlocutory decrees be taken to the House of Lords, but also those decisions which had not even attained the dignity of decrees, that is, orders. As to the reason for this, we may tentatively assign two factors. First, appeals to the House of Lords from the Lord Chancellor were established comparatively late in legal history. The chancery had come to be regarded as a court as early as the 14th or 15th Century, 30 but appeals to the House of Lords did not become established until the latter half of the 17th Century. ${ }^{* 0}$ During the intervening centuries, therefore, a given case had its beginning and ending in the same court, 41 and the only method by which a decision could be altered was by rehearing before the chancellor.42 That he reviewed all interlocutory decrees and orders made by masters in chancery may be explained historically, as originally the chancellor was the sole judge in chancery, and the masters were regarded as mere clerks rather than judges. ${ }^{13}$ Even in Blackstone's time a decree was a decree of the chancellor and not of the master who really gave it, since before it could become effective as a decree it had to be signed by the chancellor."

When the House of Lords finally asserted appellate jurisdiction over proceedings in chancery, therefore, it found a system whereby the chancellor passed on all decrees issued, as well as on interlocutory orders, and we need not be surprised that appeals were taken to the Lords from interlocutory decrees because in chancery there was no particular magic in a final decree. All were, so as to speak, of equal dignity. We might expect, however, that while appeals from all decrees would be heard, there might be some doubt as to the appealability of mere orders. This

37 The reference is now to "appeal" in the technical sense.

38 Thus, it considered the evidence already taken down, but no new evidence was admitted. Keen v. Stuckely, Gilb. Rep. 155 (1721).

391 HoLDSWORTH, op. cit. supra note 22, at 403.

40 Ibïd., 372.

11 See 1 Spence, Equitable Jurisdiction of the Court of Chascery (1846) 393.

42 A very few cases show that it was possible to get an Act of Parliament to reverse a decision of the Chancellor. 1 Holdsworth, op. cit. supra note 22, at 373 . Also by petition to the King to appoint commissioners to rehear the case. Ibid.; Vawdrey's Case, 1 Rolle Rep. 331 (1616).

131 HoLDSWORTH 416; 4 Coke, INST. 84; I SPENCE, op. cit. sippra note 41 , at 357.

\$4 3 BLACKSTONe CoMini. 453. 
supposition is borne out by Spence, who says that it was not until 1726 that appellate jurisdiction was established over interlocutory orders. 45

Second, when we consider the character of litigation handled in chancery we see how much more convenient it was to review intermediate decisions as the case progressed. Equity cases were those of which the chancellor had taken cognizance because there was no adequate remedy at law. Consequently much of its litigation was of a complicated type unsuited to the more simple common law forms of action. There was a much greater use of subordinate officials than in the common law courts, and the requirement of documentation of evidence introduced difficulties unknown to the King's courts. In equity, judgments were not compelled to follow stereotyped forms, and this made possiblo dealing with the case by as many orders, decrees, and modifications of the same as were necessary in the particular case. Thus, equity had a more elastic procedure, and also required a less rigid practice on appeal to review the many and varied steps taken below. ${ }^{48}$

\section{III}

When we pass to the American scene we are at once confronted with confusion. The almost complete lack of historical research in American legal history makes it difficult, if not impossible, to trace with any accuracy the breaking up of the old English system of dual appeals into the conglomerate mass which constitutes our modern appellate procedure. However, two main trends seem to have characterized the process.

First, there has been a general tendency to take the common law rule that error lay only after final judgment and to apply it to equity procedure. Second, hampered by this restriction in both law and equity, the courts have gone through elaborate logical exercises in order to escape from the strict application of the restriction, so that, as Coke said, "for the most part, overy particular case which has been ruled in the said books may well stand upon a several and particular reason." ${ }^{47}$

Taking up first the adoption of the common law rule into

45 1 SPENCE, op. cit. supra note 41 , at $395, \mathrm{n}$. (e). The author cites Cooper, Proceedings in Parliament (1828) 161 , but it is uncortain whether the citation refers to this particular point. A search through all chancery appeals to the House of Lords decided in 1726 fails to discloso any assertion of such jurisdiction. Likewise, a cursory examination of all such appeals up to 1800 discloses very few from what may be tormed orders. Practically all are from interlocutory or final decrees.

${ }_{46}$ Note the comparison between common law and equity proceduro in 1 SPENCE, op. cit. supra note 41 , at 389 .

${ }^{47}$ See 11 Co. 40b, 41a. 
equity, we find that this was accomplished by statute very early in the judicial history of a number of jurisdictions. Thus, the first federal judiciary act of 1789 provided for appeals from "final judgments or decrees" only.48 Ten years earlier, however, the Virginia statute setting up the court of appeals provided for an appeal from the lower court "after those decisions shall be final there." ${ }^{49}$ In Maryland the earliest statutes provided for appeals from "decretal orders," so but this was construed to mean about the same thing as final decree," and a number of years later a statute declared that appeals in equity should be from "final decrees" only." In Ohio, likewise, it was early enacted that appeals might be only from "any final sentence or decree made in any cause in chancery." "s In Missouri, on the other hand, a statute providing for chancery appeals when a party was "dissatisfied with the determination or decree" was construed to mean final decree only, by analogy with the statute applying to appeals at law. 54

481 STAT. 72 (1789). The limitation appeared in three different sections of the Act. Section 25 provided for appeals from the highest state courts to the Supreme Court; Section 22 for appeals from district courts to circuit courts, and Section 21 related to appeals in admiralty and maritime cases.

Why the statute so limited appeals must remain somewhat of a mystery. The debates in Congress for that period are too meagrely reported to be of much assistance, and although Section 25 was under considerable fire regarding the feature of appeals from state courts, no mention is made of the final judgment feature. See 1 ANNals of CoNG. 47, 51; Also Warren, New Light on the History of the Federal Judiciary Act of 17s9 (1923) 37 HaRv. L. REv. 49. Oliver Ellsworth, later Chief Justice of the Supreme Court, is generally regarded as mainly responsible for the Act. Ibid.; WARREN, History OF THE ANIERICAN Bar (1911) 240.

19 Act of (Mray): 1779 (c. 22, 10 STAT. LARg. 89). See further the Court of Appeal Law of (Oct.) 1792, VA. REv. CoDE (1794) 67 c. 11, 13 Stat. LaRg. 406 (1792). Also it may be noted that the act constituting the state Court of Admiralty of 1779 (c. 26, 10 STAT. LARG. 101) provides for an appeal from a "final sentence" of that court. See also Act of 1792 (13 STAT. LARG. 406), § 14. The foregoing are reviewed in MIcCall v. Peachy, 5 Va. 48 (1798). For further modifications of the early Virginia law, see infra note 66.

so Act of 1785, c. 72. Also see Act of 1818, c. 193.

51 Hagthorp v. Hook's Adm'rs, 1 Gill \& J. 270 (Md. 1829).

52 Act of 1830 , c. 185 . And see Hatton v. Weems, 10 Gill \& J. 377 (Md. 1839). For later modifications of the Maryland law see infra note 66.

5329 Ohio Laws 90 (1830). This was construed to forbid an appeal from a decree for the sale of mortgaged premises in a foreclosure proceeding. Baker $\nabla$. Lehman, Wright 522 (Ohio, 1834), citing the Federal Judiciary Act and a federal case decided thereunder.

51 Tanner v. Irwin, 1 MIo. 65 (1821). In Delaware the English Chancery practice was adhered to by the Constitution of 1792, by which the High Court of Errors and Appeals was given jurisdiction "to receive and determine appeals from interlocutory or final decrees of the Chancellor". Del. Laws, xliv. And see Tatem v. Gilpin, 1 Del. Ch. 13 (1816). 
Another factor which may have had some effect was the failure to keep distinct the practice of law and equity, particularly on appeal. Very commonly one appellate court was established to hear appeals in both law and equity, and in some states, at least, the common law writ of error was the method of appeal in equity cases as well as at law..$^{55}$ Such a situation could only result in the confusion of the appellate practice in those jurisdictions.

We may believe further, perhaps, that there was some reluctance on the part of the courts of appeal of those early days to decide questions of comparatively little importance, such as those generally brought up on interlocutory appeals. 50 This had doubtless been a factor at all times in the development of the rule and when congestion of dockets began to be felt it was reinforced by a stronger element, namely, the fear that if interlocutory appeals were heard it would result in the court being swamped with appeals. The merits of this belief will be discussed later; here it suffices merely to set out the fact as one of the influences which may have tended to make the final judgment rule applicable to all cases. In England we find no mention of it, but its influence in the development of our procedure can hardly be denied. Whether it appears coincident with a congested docket, or whether it was at first simply one of those "imaginary horrors" which the courts are prone to conjure up from time to time is uncertain, due to the lack of statistics as

55 Thus, in the United States Supreme Court we find tha following: "The court decided that the removal of suits from the Circuit Court into the Supreme Court must be by writ of error in every case, whatever may be the original nature of the suits." Blaine v. Ship Chas. Cartor, 4 Dall. 22 (U. S. 1800). In Alabama a writ of error which had been prosecuted from an interlocutory decree dissolving an injunction was quashed because the decision was not final. Johnson's Admr. v. Henry's Ex., Minor 13 (Ala. 1820). And see Glover v. Robinson, Minor 101 (Ala. 1822). The same practice was current in Kentucky. See Carland v. Irwin, $2 \mathrm{Ky} .1$ (1801). In fact, the entire American field of appellato prictico has tended to become more and more like the English procedure in orror. Not only is a limitation of appeal to the final judgment the rule, but tho nature of the review in most states is one of looking for errors on the record rather than considering all the facts in the case as in tho old equity appeal. See Sunderland, The Problem of Appellate Rcviow (1026) 5 TEX. L. REv. 126.

${ }^{56}$ It is also interesting to note in this connection Dean Pound's suggestion that there was considerable need directly after the Revolution to clarify and to state the extent to which the common law was to bo applied to the American scene. As a result the emphasis in tho judicial systom was upon appellate courts as instruments to lay down rules of law (seo Pound, Organization of Courts (1916) 6 BuLL. AMER. JUD. SOC. 1), and as such there must have been comparative reluctance to bother with intermediate appeals; the business of declaring the law could best be dono by considering only final judgments. 
to the appellate dockets in the early state courts. We do know something, however, through the work of Professors Fiankfurter and Landis, of the work of the United States Supreme Court in its early days. Speaking of the years immediately following the first judicial act (1789), they say: "The volume of appellate business did not yet call for relief of the Supreme Court by limiting its appellate jurisdiction." 57 During this period it is instructive to note that the cases laying down the rule are content merely to assert it,"s or to cite statutory authority.59 There is no attempt to give a moral justification.

The next forty years, however, showed a steady increase in the business activity of the country, and consequently in the business of the court. The duties of the justices were complicated by the circuit court system whereby the individual justices were supposed to ride the circuit and sit at trials in those courts. As a consequence they became greatly overworked, and many effor's were made to induce Congress to work out a better system of organization. ${ }^{\circ}$ Whether it be a coincidence merely, or whether there was some causal connection, it appears that in 1830, when congestion was increasing at a rapid rate, $\mathrm{Mr}$. Justice Story discovered that the provisions of the Act of 1789 had been all wise and far seeing in that they tended to discourage excessive appeals. He writes:

"It is of great importance to the due administration of justice, and is in the furtherance of the manifest intention of the legislature, in giving appellate jurisdiction to this court upon final judgments only, that causes should not come up here in fragments, upon successive appeals. It would occasion very great delays, and oppressive expenses." 61

Five years later, to MIr. Chief Justice MIarshall the matter has assumed the importance of "a policy which forbids writs of error" or appeals until the judgment or decree be final," ${ }^{\circ}$ while by Taney's time we know that "it was obviously the object of the law to save the unnecessary expense and delay of repeated appeals in the same suit." 63

${ }^{57}$ Frankfurter and Landis, The Business of the Supreme Court (1925) 38 HARv. L. REv. 1005, 1017.

58 Rutherford v. Fisher, 4 Dall. 22 (U. S. 1800); Young v. Grundy, 6 Cranch 51 (U. S. 1810); Gibbons v. Ogden, 6 Wheat. 448 (U. S. 1821); Kitchen v. Strawbridge, Fed. Cas. 7854 (C. C. Pa. 1821).

59 Ray v. Law, 3 Cranch 179 (U. S. 1805); Houston v. Moore, 3 Wheat. 433 (U. S. 1818).

60 Frankfurter and Landis, op. cit. supra note 57, at 1049.

${ }_{61}$ Canter, Admx. v. Amer. Ins. Co., 3 Peters 307, 318 (U. S. 1830).

62 U. S. v. Bailey, 9 Peters 272,273 (U. S. 1835).

${ }^{63}$ Forgay v. Conrad, 6 How. 201 (U. S. 1848), per Taney, C. J. This reason for the rule was also given in a number of early cases in state 
The basic principle, then, in practically all jurisdictions in this country is that only final judgments are appealable. ${ }^{04}$ When we have said this, however, we have not told the whole story.

courts. For example, "If every interlocutory order . . . be made the sub. ject of appeal ... . it would lead to an endless source of litigation." Roberts v. Stagg, 1 Nott \& Mc. 429 (S. C. 1819). And "the delny occasioned by allowing an appeal in every such case would be intolerablo". Robortson v. Bingley, 1 McCord, Eq. 333 (S. C. 1826). Also, "it is easy to porcolvo that appeals from orders of this description might be productivo of groat inconvenience and vexatious delays". Snowden v. Dorsey, $6 \mathrm{Har}$ \& J. 114, 116 (Md. 1825). Also see Joslyn v. Sappington, 1 Tenn. 222 (1806).

A refreshing protest is found in the opinion of Hosmer, C. J., of the Connecticut court, dissenting to a decision of the court that an order granting a new trial is not a final judgment. Magill v. Lyman, 6 Conn. 59 (1825). See infra note 128.

64 In practically all jurisdictions today the subject is regulated by statuto, and in most instances the rule has been modified to some extent.

Many jurisdictions allow interlocutory appeals from certain enumorated decisions or in particular kinds of actions. This is true of the procedure in the federal courts. See 43 STAT. 936, 937, 938 (1925) 28 U. S. C. $\S \S 225$ c, 227, 345 (1926); also 43 STAT. 936 (1925), 11 U. S. C. $\$ \S 47$, $48 \mathrm{a}$ (1928). It is true, also, of probably a majority of state statutes, among which see the following: Miss. CODE ANN. (1930) \& 14; MAsss. GeN. LaWs (1921) c. 231, § 96; 1 Wis. Stat. (1929) 274.09; W. VA. Codk (1931) c. 58, art. 5, § 1 ; VA. CoDE (1930) c. 267 , § 6336. S. D. CoMp. LawS (1929) § 3168; OKLA. CoMp. STAT. (1921) c. 3, art. 25, \& 780 (2); S. C. Code Crv. Proc. (1922), tit. 1, art. 2, §§ 1 (d) 2, 4; N. Y. Crv. PraO. ACT. (Cahill, 1928) $\S \S 609,610,611$; PA. STAT. ANN. (Purdon 1030) §§ 1093, 1097, 1101, 1102, 1104, 1108.

In addition to such specific exceptions to the general rule, the statutes in a few jurisdictions gave a certain amount of discrotion eithor to tho trial or to the appellate court as an alternative to appeal from the final judgment only. D. C. CoDe (1929) tit. 18, § 26; Miss. CoDE ANN. (1930) § 14; CoDE TENN. (1932) §938, applying to certain equity cases only.

Still another type of act allows appeal where the decision in tho lowor court "determines the action" or "prevents a judgment or decree". 1 Wis. STat. (1929) 274.09; S. D. Comp. LaWs (1929) § 3168\% OKLA, Comp. STAT. (1921) c. 3 , art. 25 , § 781; S. C. Code (1922) tit. 1 , art. $2, \S 1$ (d) 2; N. Y. Crv. Prac. ACT. (Cahill, 1928) § 609; Code of OHIo (Throckmorton, 1930, Baldwin's Rev.) § 12, 258

Some of these jurisdictions also allow appeals where the decision complained of "affects a substantial right". 1 Wis. STAT. (1929) 274.09; KANS. Rev. Stat. (1923) 60:3303; S. D. Comp. LAws (1929) \& 3168; OKrA. Comp. Stat. (1921) c. 3, art. 25, § 781; S. C. Code (1022) tit. 1, art. 2, $\S 1$ (d), 2, 3; N. Y. Civ. Prac. ACT (Cahill, 1928) § 609 (4); Code of OHIO (Throckmorton, 1930, Baldwin's Rev.) § 12, 258.

Other variations permit a review where the decision "adjudicatos the principles of the case". W. VA. CoDE (1931) c. 58, art. 5 § 1 (E); VA. CoDE (1930) c. 267 , § 6336; or "involves the merits". S. D. Comp. LAwS (1929) § 3168; OKLA. CoMp. StaT. (1921) c. 3, art. 25, § 780 (3); S. C. Code Crv. Proc. (1922) tit. 1, art. 2, 11 (d) 1. N. Y. Crv. Prad. ACr (Cahill, 5th ed.) § 609 (3). 
In simple actions such as those which composed most of the litigation before the original common law courts, when the case is begun and finished in a short time, the limitation of appeal to the last or final judgment works with a fair degree of convenience, but when confronted with a long and complicated case such as often characterized the old chancery litigation, it breaks down completely. Rights of the parties may be gravely jeopardized or destroyed if it is necessary to wait until the entire case has been disposed of below. If we take, for instance, an action for partition, we find there are generally many orders and decrees made during the course of the proceedings. It is often necessary to decide whether to admit or exclude parties; decrees must be made for appraisement, sale, confirmation of sale, and distribution of proceeds. Again, where there is a petition for and granting of a receivership for a business, the case may be under the control of the court for years, and obviously an appeal only from the decree winding up the case is worthless. ${ }^{\circ}$

As a result of this situation a number of escapes from the restriction have grown up. In addition to statutory modification in some states, ${ }^{\mathrm{Eg}}$ the principal method seems to have been the

${ }_{65}$ Note Forgay v. Conrad, 6 How. 201 (U. S. 1848), in which Chief Justice Taney finds it necessary to warn the circuit courts of the danger of canceling deeds and ordering property sold or delivered prior to the final judgments. The difficulty did not arise in England, he says, because appeals might be taken from interlocutory decrees in chancery.

${ }_{66}^{6}$ Supra note 64 . This tendency to make certain statutory exceptions to the rule began very early in a number of states. Thus in Virginia, by the Act of 1797 , the earlier statute allowing appeals from final judgments only (supra note 49) was modified to allow the chancellor to grant appeals at his discretion from interlocutory decrees made by him. 1 VA. REv. CODE, (1803) c. 223 , at 375 . Also see an act of Feb. 1816, c. 66, § 57, REv. CoDE, (1819), wherein further exceptions were made. Some of these early statutes are discussed in Bowyer v. Lewis, 11 Va. 553 (1807), and in Pres. \& Prof. \& Masters of Wm. \& Mary College v. Hodgson, 12 Va. 557 (180S).

In IIaryland, the Act of 1830 (supra note 52) providing for appeals from final decrees only, was amended by an act of 1841 (c. 11), providing for immediate appeals from any decree or order for the sale, conveyance or delivery of real or personal property. The act was probably passed as a result of the case of Lee v. Pindle, 11 Gill. \& J. 362 (MId. 1840), which held that an appeal could not be taken from an order of sale of slaves, when a decree for distribution of the proceeds was yet to be made. In this connection see also Dugan v. Gittings, 3 Gill. 138 (Mrd. 1845).

In Missachusetts a statute of 1782 (c. 11, section 2), provided that "any party aggrieved at the judgment of the C. P. upon any action may appeal therefrom to the next Supreme Judicial Court." This was interpieted to allow appeals from final judgments only. Tappan v. Bruen, 5 Mass. 193 (1809). By an act of 1784 (c. 27 , sec. 8), an appeal was given from judgments of respondeat ouster on a plea in abatement, and from a judgment for plaintiff on demurrer to the declaration. A statute of 1785 (c. 47) gave an appeal from the judgment quod computet in account, and that of 1786 (c. 53) from judgment quod partitio fiat in partition. Note these are all common law judgments. 
use of extraordinary remedies in the shape of writs of mandamus, prohibition, certiorari, and habeas corpus. ${ }^{07}$

Extraordinary remedies have long been recognized by appellate tribunals as means of controlling and superintending the work of the trial courts. As one court has put it, "the writs already named form a veritable arsenal of legal weapons by means of which all ordinary excesses or defaults on the part of inferior courts which call for the exercise of such power can be corrected and controlled." 68

Mandamus. At common law a mandamus issued from King's Bench and might go to any inferior court requiring them to do some particular thing "which the King's Bench has previously determined, or, at least supposes to be consonant to right and justice." 60 Its character as an escape was recognized by Lord Mansfield, who said," "When there is no specific remedy the court will grant a mandamus that justice may be done," 10 and this dictum is re-enforced by a long line of American authority beginning with Marberry $v$. Madison.71 On the other hand, it has often been said that the writ will not lie to review interlocutory proceedings, ${ }^{72}$ but the joker in the trick is that most courts make an exception when the order complained of has

In Louisiana the modern statute allowing appeals where irreparablo injury might result seems to have had its origin in early decisions. Soo Enet v. His Creditors, 4 Mart. 307 (1816), and State v. Judge Lowis, 0 Mart. 301 (1821).

6r There has also been some escape by way of refinement of the torm "final" to include orders which would seem not to be such in the ordinary sense of the term. The following "final decisions" are given not as examples of what is ordinarily held in like instances, but morely by way of illustration of the refinements which are employed to secure appeal in particular cases: order directing arbitration, Marchant v. Mead-Morrison Mfg. Co., 252 N. Y. 284, 169 N. E. 386 (1929); order to pny allimony pendente lite, Gould v. Gould, $95 \mathrm{~Pa}$. Super. Ct. 387 (1928); ordor directing defendant to answer interrogatories contained in plaintiff's bill of discover'y, Samuels v. Finkelstein, 25 S. W. (2d) 923 (Tex. Civ. App. 1930); order overruling demurrer to defense in the answer, Coleman v. Coleman, $142 \mathrm{Ky}$. 36, 133 S. W. 1003 (1911); order overruling demurrer to complaint, Mayor of Hyattsville v. Smith, 105 Md. 318, 66 Atl. 44 (1907); order refusing to dismiss attachment, Mitchell v. Eliz. River Lmb. Co., 169 N. C. 397,86 S. E. 363 (1915); order releasing attachment bond, De Bearn v. De Bearn, 119 Md. 418, 86 Atl. 1049 (1913); order refusing chango of vonuo, Carpenter v. Cent. Vt. R. R., 84 Vt. 538, 80 Atl. 657 (1911).

os State v. Johnson, 103 Wis. 591, 615, 79 N. W. 1081, 1088 (1899).

693 BLACKstone, Comm. 110.

70 Rex v. Bank of England, 2 Dougl. 524 (1780).

711 Cranch 137 (U. S. 1803).

72 Ex parte Wagner, 249 U. S. 465, 39 Sup. Ct. 317 (1919). Contra: Johnson v. Gerald, 216 Ala. 581, 113 So. 447 (1927), where it is said that mandamus is the proper method to review an interlocutory order in a divorce suit fixing alimony pendente lite. 
been issued without "jurisdiction." $* 3$

As an example of this use, we find the courts granting mandamus to review orders granting or refusing changes of venue, ${ }^{\mathrm{T}}$ declining to make persons parties to suits, ${ }^{75}$ and granting or refusing intervention. ${ }^{76}$ Again, we find it granted to correct the error of the trial court in removing a case to the equity side of the court, ${ }^{77}$ to compel a judge to require a witness to testify, and to give relief against the wrongful appointment of an auditor to simplify questions for a jury.79 All these orders against which the writ was granted are clearly interlocutory and not final in the ordinary sense of the term, so that we have in the writ a clear escape whereby interlocutory orders of the trial court may be reviewed without doing technical violence to the final judgment rule.

Prohibition. This was a writ issuing out of King's Bench "directed to the judge and parties of a suit in any inferior court, commanding them to cease from the prosecution of [some suit] upon a suggestion that either the cause originally or some collateral maiter arising therein, does not belong to that jurisdiction, but to the cognizance of some other court," ${ }^{\circ}$ it being generally familiar as the writ whereby the courts of common law asserted superiority over ecclesiastical and admiralty courts. ${ }^{81}$ Its use as an escape from the final judgment rule is shown plainly by such instances as its allowance to a party whose lien on property was displaced by an order directing the sale of it free from liens, since to wait until final judgment to appeal would have lost him his right.s2 Again, it is said that the writ will lie to correct a refusal to change venue, since an appeal from the final judgment would be valueless. ${ }^{83}$ It has likewise been used to correct an order of the trial court requiring the prosecutor to permit the accused to inspect a memorandum of evidence, ${ }^{84}$ as well as to correct the refusal of the lower court

73 People v. Smith, 275 Ill. 210, 113 N. E. 891 (1916).

74 State v. Pac. County Super. Ct., 82 Wash. 614, 144 Pac. 898 (1914); State v. Waseco County Dist. Ct., 150 Minn. 498, 185 N. W. 1019 (1921);

State v. Sup. Ct., 55 Wash. 328, 104 Pac. 607 (1909); State v. De Baun, 198 Ind. 661, 154 N. E. 492 (1926).

${ }^{75} \mathrm{Ex}$ parte Connaway, 178 U. S. 421, 20 Sup. Ct. 951 (1900).

${ }^{76} \mathrm{Ex}$ parte Breedlove, 118 Ala. 172, 24 So. 363 (1898); Riverside Iron

Works v. Hosmer, 100 Mich. 124, 58 N. W. 693 (1894).

$\pi \mathrm{Ex}$ parte Simmons, 247 U. S. 231, 38 Sup. Ct. 497 (1918).

78 Woolley v. Wight, 65 Utah 619, 238 Pac. 1114 (1925).

79 Ex parte Peterson, 253 U. S. 300, 40 Sup. Ct. 543 (1920).

803 Blackstone, CoMin. 112.

811 HOLDSTORTH, 229, 553, 558, 594-5.

82 Oldroyd v. IIcCrea, 65 Utah 142, 235 Pac. 580 (1925).

${ }^{83}$ State v. Super. Ct., 97 Wash. 358, 166 Pac. 680 (1917).

s4 People v. Sup. Ct., 245 N. Y. 24, 156 N. E. 84 (1927). 
to dismiss a prosecution on the motion of the county attorney. ${ }^{86}$ Another instance is its use to correct an instruction of the court to commissioners who are about to assess property in eminent domain proceedings. ${ }^{86}$

Certiorari. This writ presents a problem slightly different from the two just discussed. Originally it issued out of chancery or King's Bench, ordering the record to be sent up "to the end the party may have more speedy justice." ${ }^{87}$ At common law, apparently, it was employed chiefly in three types of cases. First, to bring up an indictment before trial in order to pass on its validity, or to insure a fair trial. Second, as a "quasi-writ of error" to review judgments of inferior courts, particularly those proceeding other than according to the course of the common law, from which error did not lie. Third, to bring up out branches of the record on matters omitted on the return of the writ of error. ${ }^{88}$

In this country, however, its character in many jurisdictions has been greatly changed. Because of its discretionary character it has been used as an instrument to secure discretionary appeals in some cases ${ }^{89}$ and when used as a substitute for a writ of error in this way it has been widely held that it cannot be sued out until final judgment.90 That it is still used to some extent as an escape from the rule, however, we see from cases holding that it will be issued to review failure to allow a change of venue, ${ }^{91}$ to review an order removing an administrator, ${ }^{02}$ and to correct an order directing a receiver to sell where the supersedeas bond on appeal could not be executed in time to prevent the sale. ${ }^{.3}$ Its character as an escape has been frankly recognized in a number of cases as where it is said that certiorari

85 Foley v. Ham, 102 Kan. 66, 169 Pac. 183 (1917).

86 Peters v. Buckner, 288 Mo. 618, 232 S. W. 1024 (1921).

87 BACON'S ABRIDGMENT, Certiorari (a).

88 Hartranft v. Mollowny, 247 U. S. 295, 38 Sup. Ct. 518 (1018); Cf. 4 BLACKSTONE, Comm. 320 , in which most of the discussion relates to its use in bringing up the indictment in criminal cases.

89 See cases cited, 28 U. S. C. A. 347 (1928) and also 2 Sremlina, EXTRAORDINARY RELIEF (1901) § 1914.

${ }^{00}$ Gurnilla v. Industrial Accident Comm., 187 Cal. 638, 203 Pac. 307 (1921) ; State v. Dist. Ct., 134 Minn. 435, 159 N. W. 965 (1016). For further cases see those cited in 11 C. J. 126, note 62. Also see samo volumo, $\S 76$ and citations.

91 Carpenter v. Cent. Vt. R. R., 84 Vt. 538, 80 Atl. 657 (1911). Noto that orders involving changes of venue, which are clearly interlocutory, have been reviewed by mandamus (note 74), prohibition (noto 83), and now certiorari, although in the first two instances it was becauso ordinary appeal from the final judgment would be valueless, while in the Carpentor case certiorari is allowed because the order is deemed a final judgmont. 82 Haddick v. Dist. Ct., 160 Iowa 487, 141 N. W. 925 (1913).

93 State v. Super. Ct., 110 Wash. 559, 188 Pac. 384 (1920). 
may be used to review interlocutory decrees where irreparable injury would result by waiting to appeal from the final decree.06

Habeas Corpus. It is often said that habeas corpus is not a substitute for an appeal or writ of error, ${ }^{95}$ but these statements are generally made in cases which have gone to final judgment, and were therefore appealable by the regular method. Like mandamus or prohibition it is made use of when the lower court has exceeded its jurisdiction, and thus is open to use to free persons prior to final disposition of the case. Thus it will lie before conviction when an information fails entirely to show any offense under the statute which defendant is said to have violated, ${ }^{96}$ and to test the jurisdiction of the committing magistrate. ${ }^{37}$ Moreover, when there is no legal evidence that a crime has been committed, or that the prisoner has committed one, he is entitled to the writ. ${ }^{38}$ These are familiar enough examples of the use of the writ to release in advance of trial persons wrongfully held in custody, and as such, it is a clear escape from the rule requiring a final judgment before appeal can be taken.

I have noted heretofore that it is generally thought that the rule requiring final judgments before appeals can be taken was invoked in order to prevent congestion in the appellate court. ${ }^{.3}$ If we assume that no restriction at all would result in a multiplicity of appeals, and if we assume further that restriction is always desirable, it still remains to be seen whether attempting to restrict them by a rule requiring final judgments is at all successful. It is true that to some extent it prevents a case from being presented for review in fragments but, on the other hand, it has caused protracted and repeated litigation over the question of what judgments and orders are final. As Professor Sunderland has put it:

"There is one thing to be said in favor of no restrictions at all,-it will save an immense amount of useless litigation over the question whether parties may or may not appeal particular

94 MacKenzie v. R. I. Hospital Trust Co., 45 R. I. 407, 122 Atl. 774 (1923) ; cf. Lavoy v. Toye Bros., 159 La. 209, 105 So. 292 (1925), wherein it is said that certiorari and prohibition are proper methods of attacking proceedings outside the jurisdiction of the lower court, appeal not always being adequate.

95 MicMicking v. Schields, 238 U. S. 99, 107, 25 Sup. Ct. 665, 667.

${ }^{96}$ Ex parte Garvey, 84 Fla. 583, 94 So. 381 (1922).

${ }^{97}$ People v. Snell, 216 N. Y. 527, 111 N. E. 50 (1916).

${ }^{98}$ State v. Huegin, 110 Wis. 189, 85 N. W. 1046 (1901); Comm. v. Shorthall, 206 Pa. St. 165, 55 Atl. 952 (1903).

${ }^{99}$ Supra part $\mathrm{I}$. 
cases. Every restriction to ward off appeals creates litigation over the force and effect of the restriction itself. Machinery to save labor may become so complex as to waste more labor than it saves." 100

It would not be surprising if this be true of the final judgment rule. What is sought to be accomplished is to label a definite point in a given case as "final," and to allow appeals only when that point has been reached. This procedure necessarily involves a satisfactory definition of "final" which will be recognizable with a minimum of uncertainty, and which, when applied to the case at hand will yield information as to whether that final stage has been reached. The difficulty lies just at this point. In law, as in any other field, the value of any definition in so far as it aids in classifying or describing specific facts or cases, varies inversely to its degree of generality. Yet when we say that only final judgments are appealable we are assuming that all the law, the entire corpus juris, can be brought under a single definition, which, when applied to a given case, will disclose automatically" whether the desired stage in its progress has been reached.

These considerations, then, should prepare us for the large volume of litigation over the question of what constitutes a final judgment,' and we should not be surprised at the spectacle of a labor saving device which causes more labor than it saves. Wo are really seeking to determine whether this is the sort of decision which the appellate court wishes to hear, but we spend our time arguing the question of whether the decision is an final judgment. As the number of cases increase, generalizations which were used in past times must be reformulated, or cast aside for new ones which are yet more vague or which contain words capable of more than one meaning. Thus we create machines within machines in order to exclude or include given sets of cases as the situation may require. And since so many different kinds of cases are included in these generalizations, learned counsel are able to parade a vast army of decisions for the edification of the court, although the subject matter involved in them is entirely different from the case which is being argued. ${ }^{101}$

As an illustration of this procedure, a recent case in the federal courts is very much in point. ${ }^{102}$ The appeal was from the denial of a motion for an order reviving and continuing an action to recover damages sustained through unlawful combination and

100 Sunderland, The Problem of Appellate Review, op. cit. supra noto 55, at 127 .

101 See Professor Arnold's treatment of this tendency in another ficld. Criminal Attempts-The Rise and Fall of an Abstraction (1930) 40 YALE L. J. 53.

102 Sullivan v. Associated Billposters, 6 F. (2d) 1000 (C. C. A. 2d, 1025). 
conspiracy among the defendants, resulting in the destruction of plaintiff's business. The motion sought to revive the action against the executors of a defendant who had died after the action was brought. The plaintiff in error sought to convince the court that the motion was appealable by the citation, inter alia, of the following cases in which the decisions indicated were held to be final: ${ }^{103}$ an order committing a witness for contempt, ${ }^{10}$ a decree in a foreclosure suit of a railroad fixing compensation of a trustee; ${ }^{105}$ an order allowing a district attorney to take custody of exhibits used in a civil suit in order to use them against the witness in a criminal prosecution; ${ }^{100}$ a decree awarding costs and execution thereon rendered in a mortgage foreclosure; ${ }^{107}$ an award of compensation to a receiver for the past years services in a proceeding to wind up a partnership; ${ }^{108}$ a decree conditionally dissolving an attachment in an action at law in which a third party intervened alleging that the attached property was held in trust for the intervenor; ${ }^{20}$ a decree dismissing a bill as to one of two copyrights in an action to restrain enfringement; ${ }^{110}$ and an order making a temporary injunction permanent in an action by a receiver in a judgment creditor's suit to restrain a city from passing a resolution forfeiting a charter.111

But not only does a given case often have a fine variety of antecedents, but its results may be even more surprising. At the risk of prolonging the sport unduly, let us survey some of the bastard progeny of one of the leading cases defining a final judgment, MicGourkey $v$. Toledo \& Ohio $R y .{ }^{112}$ This case did not involve the concept of the final judgment in connection with an appeal. The problem there was whether in a mortgage foreclosure of a railroad, turning property over to a receiver was a final decree which the court could not disturb by a subsequent decree. When we examine the cases in which it has been cited, however, we find that its definition of a final judgment for the purpose of determining whether a decree may be altered after the expiration of the term, is used to define a final judgment for the purpose of determining when an appeal will lie.113 The many

103 See epitomized brief of counsel, 42 A. L. R. 505 (1026).

${ }^{104}$ Butler v. Fayerweather, 91 Fed. 458 (C. C. A. 2d, 1899).

105 Williams v. IIorgan, 111 U. S. 684, 4 Sup. Ct. 038 (1884).

${ }^{106}$ Perlman v. U. S., 247 U. S. 7, 38 Sup. Ct. 417 (1918).

${ }_{107}$ In re Michigan Central R. R. 124 Fed. 727 (C. C. A. 6th, 1903).

108 Ruggles v. Patton, 143 Fed. 312 (C. C. A. 6th, 1906).

$109 \mathrm{MICDermott}$ v. Hayes, 197 Fed. 129 (C. C. A. 1st, 1912).

110 Hist. Pub. Co. v. Jones Bros. 231 Fed. 784 (C. C. A. 3d, 1916).

${ }^{111}$ Gas \& Elec. Sec. Co. v. MIan. \& Queens Trac. Corp., 260 Fed. 625

(C. C. A. 2d, 1920).

112146 U. S. 536, 13 Sup. Ct. 170 (1892).

${ }^{113} \mathrm{An}$ interesting example of this practice of confusing a final judgment 
different situations brought under the same rule should also be noted in the following cases, each of which held the order or decree involved not to be final: appointment of commissioners in condemnation proceedings; ${ }^{114}$ an order for seizure and sale of mortgaged land under executory process in Louisiana; ${ }^{115}$ a decree which determined that a partnership existed and that one partner was entitled to a share of the profits, but which referred the case to a master to state an account; ${ }^{110}$ an order of an appellate court directing the trial court to enter an order prayed for by an intervenor that plaintiff in an action against the officers of a bank turn over to the intervenor the money and stock paid by defendants to plaintiffs in settlement of that suit, but providing that plaintiff should have costs and attorney's fees; ${ }^{117}$ and a decree in a suit to enjoin collection of a $\operatorname{tax}$ restraining collection for years prior to 1900 , but reserving for further consideration those levied in 1900 and thereafter. ${ }^{118}$

Up to this point, therefore, I have sought to show that, assuming restriction of appeals to be desirable in all cases, the concept of the final judgment is wholly unsatisfactory as a

for the purpose of determining appellability with a final judgmont for the purpose of determining whether it is within the power of the court making the order to change it, is seen in 2 R. C. L. $\$ 22$, at 40 . Thore, in connection with appeal it is said that a final judgment is ono that operatos "to divest some right in such a manner as to put it out of the pawor of the court making the order to place the parties in their original condition after the expixation of the term." Incidentally, if we turn to $15 \mathrm{R}$. C. L., $\S 129$, at 678 , for help in determining when the court may or may not place the parties in their original position, we are told that it is only a final judgment which cannot be so amended.

114 Luxton v. North River Bridge Co., 147 U. S. 337, 13 Sup. Ct. 356 (1893).

115 Fleitas v. Richardson, 147 U. S. 538, 13 Sup. Ct. 429 (1893).

116 Latta v. Kilbourn, 150 U. S. 524, 14 Sup. Ct. 201 (1893).

117 Calif. Nat. Bank v. Stateler, 171 U. S. 447, 19 Sup. Ct. 6 (1898).

118 Covington v. First Nat. Bank, 185 U. S. 270, 22 Sup. Ct. 645 (1902).

Also a decree confirming the report of commissioners in a partition salo, ordering a conveyance and sale, with such distribution as might bo orderod when the sale was confirmed. Clark v. Roller, 199 U. S. 541, 26 Sup. Ct. 14 (1905). A decree in admiralty in a proceeding for limitation of liability, holding that plaintiff is entitled to the limitation as to one class of claims, and remitting question as to other claims for proof. La Bourgogno, 210 U. S. 95, 28 Sup. Ct. 664 (1908). In a suit to cancel deeds to growing timber, and to enjoin defendant from cutting the same, a decree adjudging defendant to have the right of possession, but appointing a master to tako further evidence as to the identity of trees covered by the deeds. Rexford v. Brunswick Co., 228 U. S. 339,33 Sup. Ct. 515 (1913).

I have noted only some of the decisions in the United States Supromo Court in which the McGourkey case has been used as a criterion for dotormining a final judgment. It has also been cited in forty some cases in the federal district and circuit courts, with results which can readily bo imagined. 
method of accomplishing that result. However, it would seem that restriction, even if it be desirable as an ultimate goal, should not be exercised blindly. The needs of the appellate court must be considered, of course, but they are not the only parties interested in the appeal. Since courts are organized primarily to serve litigants, their needs cannot be ignored, nor can we put the trial court entirely out of view. Since the appellate courts have the last word, however, and since they write the opinions, we have tended to view the problem mainly from the point of view of their special difficulty, that is, the danger of excessive appeals.

Looking at the matter from the standpoint of the trial court, we see that when an appeal is sought from a given decision, as for instance, when a demurrer to a complaint has been overruled, or a motion to dismiss denied, there exists what might be termed a conflict of interest between the trial and appellate courts. It is to the advantage of the trial court to have the question of whether the plaintiff has a cause of action determined at once by the appellate court, for if he has not, a trial will be unnecessary. On the other hand, the appellate court will prefer, especially if its calendar is crowded, not to pass upon the question until the trial is had and judgment rendered, thus obviatıng the possibility of more than one appeal. Since there are physical limitations to the amount of work which can be done by each court, the rules of appeal should be a compromise between the needs of each. The rule requiring a final judgment before appeal, howevèr, if rigidly adhered to, relieves only the strain upon the reviewing court, and the trial court is left to dispose of its docket as best it can. Perhaps the relief which could be afforded by a more flexible method of determining when appeals should be allowed would be small, but there is at least opportunity for intelligent experimentation. There is no particular reason why the decisions which may be appealed should be the same yesterday, today and forever, but rather the courts might use the process to control to at least a limited extent the amount of business done by each.

Now as to the litigants, it is rather obvious that to allow or disallow appeals upon the basis of whether or not the final judgment has been rendered is to ignore wholly the needs created by the particular situation. If in a partition suit there is a decree for the sale of property of which defendant claims to be the sole owner, he will not look kindly. upon a decision on appeal which says that he may not obtain a review of the case until the sale has been made and the proceeds distributed.119 Again, when

119 Forgay v. Conrad, supra, note 65, illustrates this point very well. But of course its operation is no worse than that of many other rules of thumb. 
alimony pendente lite has been granted in a divorce suit, are we to determine whether an appeal shall be allowed upon the arbitrary basis of whether or not it is a final judgment, ${ }^{120}$ or shall we take into consideration the fact that to refuse an appeal will deprive the husband of any review at all, since an appenl from the final decree is likely to be worthless so far as the money already paid out is concerned.221

In other words, it should be recognized that all cases are not alike; that the need for an appeal may not arise at the same stage in a partition case or a divorce suit that it does in replevin or in an action on a promissory note.

Aside from these considerations, moreover, there is a further danger involved. Statutes generally provide a set time within which the appeal may be taken, and if it is not brought within that time the right to a review is lost. Now where there is some doubt as to just which decree is the final one, the litigant is compelled to choose between the horns of a dilemma. If he appeals from one decree he may be thrown out of court because it is not final, while if he waits until a subsequent time to appenl he may be told that the first decree was the final one and thus he has lost his chance of appeal. Illustrating this was a case decided in the Supreme Court of Alabama in 1923.122 There certain equities of the case were decided in favor of the plaintiff, with reference to a register to state an account. An appeal was taken from the decree rendered after the accounting, but more than six months after the first decree. The court held that the first decree was the final one, and the statutory time having elapsed, plaintiff had lost his right to appeal.

As a consequence of the foregoing, the final judgment would seem to be a wholly inadequate criterion to determine whether an appeal should be allowed from a given decision. Favored by appellate courts because it seems to restrict appeals, it would appear upon analysis to cause about as much labor as it saves, because it requires repeated litigation over the question of what

120 In Earls v. Earls, 26 Kan. 178 (1881) such a decree was held unappealable because not a final judgment. The opposite was held in Sharon v. Sharon, 67 Cal. 185, 7 Pac. 456, 635, 8 Pac. 709 (1885). Compare Call v. Call, 65 Me. 407 (1876), and McKennon v. McKennon, 10 Okla. 400, 63 Pac. 704 (1900), where a more realistic treatment was adopted.

121 It may be worth while here to quote the words of a Connecticut judge, who uttered them over a century ago:

"If the exror is reviewed, after the determination of the action at lnw, how inequitable and ruinous the delay! Years may elapse beforo this event takes place, and in the meantime the action may run tho wholo round of litigation until it is exhausted to the dregs, and the party is deprived of property in this unnecessary conflict much beyond the wholo value of the matter in question." Magill v. Lyman, supra note 68, at 67. 122 Burgin v. Sugg, 210 Ala. 142, 97 So. 216 (1923). 
is or is not a final judgment. Faced with this situation, and with the fact that it has no relation to the problems of the trial court nor to the needs of the parties in a particular case, we should be prepared to examine the possibilities of discarding the rule as an instrument for controlling appeals, in favor of some method more elastic and more capable of meeting the difficulties raised by our modern judicial system.

\section{VI}

Since we may expect with assurance that appeals will continue to be taken in a vast number of cases, some method of sorting out those which are to be heard must be provided. If we discard the final judgment rule as a means to this end, what can we offer to replace it?

One possibility lies in an increase of the statutory exceptions to the rule. By this method injustice to litigants in certain specified types of cases may be avoided, although it does not touch the difficulty in the vast majority of cases left to be governed by the old rule, where the concept of the final judgment gives no accurate criterion by which the question of the time for appeal may be decided.

Again, the use of the extraordinary wits, mandamus, prohibition, certiorari, and habeas colpus, together with the injunction, might be expected to give relief in certain types of cases if used more frequently, but the difficulty here is that the greater use made of them the more uncertain it becomes just what remedy should be pursued in a given instance. The principle of res adjudicata invariably works for confusion where there are a number of different remedies used to attain practically the same result, and even now the books are full of cases where it is said that the wrong method has been used to bring the dispute before the appellate court. ${ }^{123}$ The litigant is therefore confronted by the question of whether he will try mandamus, or prohibition, or whether after all the decision may not be a final one and thus reviewable by writ of error or appeal to the exclusion of the extraordinary remedies.

One ameliorating influence beginning to be felt might be mentioned at this time, namely the crystalization of the rules in certain type situations. That is, after a great many cases have been decided in a given jurisdiction, the very fact of the existence of such a mass of authority tends to compel counsel to exercise some discrimination in their citation of authority, with the result that the court may come nearer to a consideration of

${ }^{123}$ See Sunderland, op. cit. supra note 55, at 129-131. "The choice bristles with perplexing dilemmas." 
the appeal on the merits, or in other words, to deciding whether it is the type of case, which, for various reasons, should be heard on appeal. In a decision of that type, there will not be much talk about the final judgment, but only whether this is the kind of case the court wants to hear on appeal. This tendency is illustrated in a recent opinion in the United States Supreme Court by Mr. Justice Brandeis, ${ }^{124}$ in which he held that an order of the district court denying an application of a defendant under the National Prohibition Act for a return of papers taken from him without warrant, and for the suppression of evidence obtained therefrom, was not appealable. There is little or no talk in the opinion about what is or is not a final judgment, but it is merely said that in cases of this type appeal will not be allowed.

In view of the disinclination of courts to adopt radical changes it is probable that any improvement in conditions in the nenr future will be brought about by the method just described. Nevertheless, it seems to the writer that the basic difficulty in the whole matter will not be solved until the appellate court is given a complete discretionary power as to the cases which it will review. The statute providing for appeals could be patterned after the English system, with appeals only by leave either of the trial or of the appellate court. ${ }^{225}$ If thought desirable appenls could be allowed as of right from certain specified decisions in particular cases, such as those in the criminal field.

Counsel seeking an appeal would present a simple petition or application for review, setting out the reasons why this particular case should be heard. If the situation has been analyzed correctly in the foregoing discussion, the problem of whether the application should be granted involves a number of considerations. There are physical limitations to the amount of work which a trial or appellate court can do, and a balancing of conveniences between them must be the primary factor in deciding whether to review the case. Second, the court will want to consider the effect upon the litigant if the appeal is to be denied. The question is, will a denial of review work substantial injustice. ${ }^{126}$ If so, then the court will want to hear it if at all possible in view of the amount of work before the court.

Probably the greatest objection which will be urged against a discretionary appeal is the claim that the court would be

124 Cogen v. U. S. 278 U. S. 221,48 Sup. Ct. 436 (1929).

125 Supreme Court of Judicature Act, $1925,15 \& 16$ GEo. V, c. 49, § 27031; 4 Hals. Stat. 159-161. And see Ruf. \& Co., Ltd. v. Pauwols, L. R. [1919] 1 K. B. 660 .

126 If it be objected that the words, "substantial injustice," are vaguo, the answer is that it is to be hoped they will be so vague that no court will try to define them in the abstract. The phrase, "final judgmont," gives a misleading sense of concreteness, with the consequence that frequent attempts to define it give rise to all the trouble related in part $V$ of the toxt. 
swamped with petitions for review. ${ }^{127}$ It seems likely to the writer that the restrictive influence of the final judgment rule has been overestimated, but in any case the matter can be settled only by experiment. Certainly a hardboiled appellate court could go a good way toward handling a large number of petitions. Each justice could be assigned a certain number for his attention, and he could weed out those brought on frivolous points, or upon a type of decision which the court had previously agreed not to review. Doubtful cases could then be considered by the whole court if thought necessary. Long petitions would be taboo because no one would read them, and the attorney who put his case in a concise manner would be the one to get a hearing. Under such a system, a drastic curtailment of the types of cases in which appeals would be allowed might help to educate the bar to the point where they would cease to attempt to appeal every case, which after all, is the greatest difficulty involved.

${ }_{127}$ The result of establishing a discretionary appeal by certiorari in the United States Supreme Court has given some credence to this view. Petitions for certiorari have increased steadily since enactment of the statute, and in the October Term, 1929, there were 692 applications for certiorari. See Frankfurter and Landis, The Business of The Supreme Court at October Term, 1929 (1930) 44 HARv. I. Rev. 1. But it should also be noted that the Supreme Court has recently shown itself well able to keep abreast of its work. See Frankfurter and Landis, The Business of the Supreme Court at October Term, 1930 (1931) 45 HARv. L. REv. 271. 